\title{
AquaStat: An Arduino-based Water Quality Monitoring Device for Fish Kill Prevention in Tilapia Aquaculture using Fuzzy Logic
}

\author{
Mark Rennel D. Molato \\ Institute of Information and Communication Technology \\ Isabela State University - San Mariano Campus, San Mariano, Isabela, Philippines, 3332
}

\begin{abstract}
In the Philippines, Tilapia fish farming sector is vital to the economy in providing substantial employment, income and meeting local demand for protein sources of the Filipinos. However, the possible benefits that can be derived from this industry are at stake because of the sudden occurrences of fish kill events. This can be attributed to a wide variety of natural and unnatural causes such as old age, starvation, body injury, stress, suffocation, water pollution, diseases, parasites, predation, toxic algae, severe weather, and other reasons. With the identified severe effects of fish kill events to the fish farmers, consumers and the fisheries industry, advanced measures and methods must be established to alleviate the adverse effects of this phenomenon. To solve the underlying problem on water quality monitoring system to improve freshwater aquaculture, various studies were already conducted. However, these studies merely focused on the reading and gathering of water parameters. In this paper, fuzzy logic was used to come up with a model that can analyze and generate result regarding the overall quality of the water being used in Tilapia aquaculture. The water parameters considered in this paper were temperature, dissolved oxygen, and $\mathrm{pH}$ level. The results of the water parameter readings using the conventional method were compared to the data that were gathered by AquaStat to test its accuracy and showed no significant difference. Also, the overall water quality obtained using the conventional method was compared to the overall water quality generated by AquaStat and obtained an accurate result.
\end{abstract}

Keywords-Fuzzy logic; fuzzy sets; fish kill; freshwater aquaculture; Tilapia

\section{INTRODUCTION}

The Philippines is positioned as the 8th top fish producing country in the world. It has a total inland resource of 749,917 ha as reported by the Bureau of Fisheries and Aquatic Resources employing a combined total of 1,614, 368 fishing operators nationwide. Moreover, aquaculture got the highest percentage of total fish production from 2018 - 2020 with $52.8 \%$ share to overall total fish produced [1]. This sector produces tons of fish, crustaceans, mollusk, and aquatic plants which contribute to the national economy of the country having the largest share next to agricultural crops at current and constant prices[2].

Tilapia (Oreochromis niloticus) ranked second among the fish species that are being produced in aquaculture in the Philippines [3]. Moreover, it is identified as the most consumed aquaculture fish in the Philippines for its taste and affordability [4], [5].

However, there is an indicative fall of the potential benefits of the aquaculture industry in the Philippines because of the occurrences of fish kill incidents directly harming fishing operators. The fish kill is a sudden mass death of the fish in any given body of water[6]. Also, it is defined as any unusual and noticeable increase in mortality due to infectious or noninfectious causes like oxygen depletion, pollutants, natural toxins and diseases in aquatic organisms [7]. It is characterized by large numbers of aquatic animals dying over a short time in any bodies of water where fish cultivation was being pursued [8].

Fish kills can be attributed to a wide variety of natural and unnatural causes such as old age, starvation, body injury, stress, suffocation, water pollution, diseases, parasites, predation, toxic algae, severe weather, human-induced activities, and other reasons. However, most fish kills result from natural events[9]. The authority attributed the Lake Sebu fish kill event in South Cotabato last January 2021 to the sudden change of weather in the area[10]. Also, extremely high temperature has been identified as a potential agent that could cause fish kill events.

With the identified severe effects of fish kills to the fish farmers, consumers and the fisheries industry, advanced measures and methods must be established to alleviate the adverse effects of fish kill events.

To solve the underlying problem on water quality monitoring, various studies were conducted. The studies presented in [11], [12], [13], [14], and [15] used water sensors and IoT technology to conduct real-time water quality monitoring. However, these studies focused only on the reading and gathering of water parameters.

To solve this, various researchers presented studies that used fuzzy logic to automatically analyze the water quality without the human intervention.

In the study of Caldo and Dedios [16], they categorized the inputs as physical, chemical, and micro biological in the fuzzy inference system to analyze the water quality in Taal Lake. Rana and Rani [17] conducted a MATLAB simulation of a fuzzy logic system to determine the percentage of fish health in freshwater using temperature, dissolved oxygen, and 
conductivity. In the study of Ichsan, Kurniawan and Huda [18], they designed a fuzzy logic control based on graphical programming to monitor the water quality in shrimp pond by considering the salinity and turbidity. Hiyunissa, Alam and Salim [19] designed fuzzy logic control system to control microbubble aeration to maintain a desirable value of dissolved oxygen. They only considered the DO and the water temperature. Bokingkito and caparida [20] implemented an IoT-based real - time water quality assessment monitoring system for freshwater aquaculture they considered temperature, $\mathrm{pH}$ and turbidity.

Despite the notable results of the studies presented above, their scopes were focused mainly on the assessment of the water used in freshwater aquaculture in general. However, diverse freshwater species have their own tolerance to various water parameters [21] and the desirable ranges of water parameters vary in every freshwater specie.

Hence, this study developed a fuzzy logic-based water quality assessment, specifically focused on Tilapia aquaculture. This study considered $\mathrm{pH}, \mathrm{DO}$ and temperature as inputs to the fuzzy inference system.

\section{THE SYSTEM MODEL}

\section{A. Water Parameters}

With the significant profit gained from the aquaculture industry, measures must be taken into consideration to ensure aquaculture's production growth to continuously contribute to the different pattern of supply and demand for fish and fish products. Poor water yields to poor product quality thus this becomes a potential risk to human safety. Also, production is reduced when the water contains contaminants that can impair development, growth, reproduction, or even cause mortality to the cultured species [22].

Massive fish kill events are mostly associated with a sudden change in water composition due to natural causes. Fish kills occur most frequently during the summer when water temperature is high and dissolved oxygen levels are low[23]. Although there is a wide variety of natural and unnatural causes of fish kill incidents, the following are just the identified water parameters that mostly caused sudden massive Tilapia fish kill incidents in the Philippines that need to be monitored in a regular basis.

The first parameter is the water temperature. Water temperature can adversely affect the water condition. Both low and high heat can directly influence other important components that are beneficial in ensuring the health of the marine species [24].

Second is the $\mathrm{pH}$ level. The $\mathrm{pH}$ concentration of the water can affect the aquatic organisms' health. In freshwaters, inadequate $\mathrm{pH}$ levels can hasten the release of metals from rocks and sediments. These eventually affect the metabolism of the fish and its ability to take up water through the gills. Furthermore, low $\mathrm{pH}$ can condense the amount of dissolved inorganic phosphorus and carbon dioxide available for phytoplankton during photosynthesis. In contrast, high $\mathrm{pH}$ levels can turn the toxic form of ammonia, become more predominant, and the phosphate can rapidly precipitate [22].
And the most important water parameter is the Dissolved Oxygen (DO). Fish needs dissolved oxygen to breathe and perform metabolic activities. Thus, an inadequate level of dissolved oxygen is often associated with fish kill events. Alternatively, precise levels can result in good growth leading to high production yield [22].

\section{B. Desirable Ranges of Water Parameters}

The tolerance of diverse aquamarine species to several water parameters varies.

Table I shows the water quality standards for Tilapia Freshwater Aquaculture in the Philippines [21]. It contains the three (3) identified parameters that are crucial in fish kill incidents together with their desirable ranges.

TABLE I. WATER QUALITY STANDARDS FOR TILAPIA AQUACULTURE IN THE PHILIPPINES

\begin{tabular}{|l|l|}
\hline Water Parameters & Desirable Range/s \\
\hline Temperature & $25-32{ }^{\circ} \mathrm{C}$ \\
\hline Dissolved Oxygen (DO) & $3-5 \mathrm{mg} / \mathrm{L}$ \\
\hline pH Level & $6.5-9$ \\
\hline
\end{tabular}

\section{Development of the Fuzzy Inference System}

There are numerous water parameters that can cause fish kill incidents, however, with the recommendation of an expert ${ }^{1}$ in the field of freshwater aquaculture, this paper only focused on the three (3) identified water parameters that caused most of the sudden Tilapia fish kill occurrences. Also, the said expert helped in defining the linguistic values and universe of discourse for each input parameter. Matlab R2018b was used in designing the fuzzy inference system.

In designing the fuzzy inference system of the three (3) inputs, the Membership Function (MF) type used was trapezoidal (1) because there are ranges from a single linguistic value that are equal regarding the degree of membership.

$f(x ; a, b, c, d)=\max \left(\min \left(\frac{x-a}{b-a}, 1, \frac{d-x}{d-c}\right), 0\right)$

where $\mathrm{x}$ is the input value while parameters $\mathrm{b}$ and $\mathrm{c}$ define the shoulders of the membership function, and a and define its feet.

In designing the fuzzy inference system of the output, the triangular membership function (2) was used.

$f(x ; a, b, c)=\max \left(\min \left(\frac{x-a}{b-a}, \frac{c-x}{c-b}\right), 0\right)$

where $x$ is the input value while parameters $a$ and $c$ define the feet of the membership function, and $b$ defines its peak.

The Mamdani Fuzzy Inference System model was used in this paper because of its ability to synthesize a set of linguistic control rules obtained from a human expert and because it has more intuitive and easier to understand rule bases suited to expert system applications [25].

${ }^{1}$ Dr. John Henry R. Centeno III, Fish Health Specialist, Fish Health Laboratory, Bureau of Fisheries and Aquatic Resources, San Mateo, Isabela, Philippines, johnhenrycenteno@gmail.com. 
In creating the rules, the logical AND operator was used. The AND operator was used to combine the different antecedents because the value of each input has a significant impact on each other.

And finally, the Center of Area (3) was used for the defuzzification process.

$\operatorname{CoA}=\sum_{i} \mu\left(x_{i}\right) x_{i} / \sum_{i} \mu\left(x_{i}\right)$

where $\mu\left(x_{i}\right)$ is the membership value for point $x_{i}$ in the universe of discourse.

Table II shows the inputs, their linguistic values, Membership Function types and universe of discourse of each water parameter and the structure of the output of this fuzzy inference model.

TABLE II. INPUTS, LINGUISTIC VALUES, MF TYPE AND UNIVERSE OF DISCOURSE

\begin{tabular}{|c|c|c|c|}
\hline Inputs & $\begin{array}{l}\text { Linguistic } \\
\text { Values }\end{array}$ & MF Type & $\begin{array}{l}\text { Universe of } \\
\text { Discourse }\end{array}$ \\
\hline Temperature & $\begin{array}{l}\text { Low } \\
\text { Normal } \\
\text { High }\end{array}$ & $\begin{array}{l}\text { trapmf } \\
\text { trapmf } \\
\text { trapmf }\end{array}$ & $\begin{array}{l}{\left[\begin{array}{llll}12 & 12 & 19 & 28.5\end{array}\right]} \\
{\left[\begin{array}{llll}21.5 & 25 & 32 & 35.5\end{array}\right]} \\
{\left[\begin{array}{llll}28.538 & 42 & 42\end{array}\right]}\end{array}$ \\
\hline $\begin{array}{l}\text { Dissolved Oxygen } \\
\text { (DO) }\end{array}$ & $\begin{array}{l}\text { Low } \\
\text { Normal }\end{array}$ & $\begin{array}{l}\text { trapmf } \\
\text { trapmf }\end{array}$ & $\begin{array}{l}{\left[\begin{array}{llll}0 & 0 & 1.5 & 3.5\end{array}\right]} \\
{\left[\begin{array}{llll}2.5 & 4.5 & 5 & 5\end{array}\right]}\end{array}$ \\
\hline pH Level & $\begin{array}{l}\text { Acidic } \\
\text { Neutral } \\
\text { Basic } \\
\end{array}$ & $\begin{array}{l}\text { trapmf } \\
\text { trapmf } \\
\text { trapmf }\end{array}$ & $\begin{array}{l}{\left[\begin{array}{llll}1 & 1 & 4 & 7.25\end{array}\right]} \\
{\left[\begin{array}{llll}5.25 & 6.5 & 9 & 10.25\end{array}\right]} \\
{\left[\begin{array}{lllll}7.75 & 11 & 14 & 14\end{array}\right]} \\
\end{array}$ \\
\hline Output & $\begin{array}{l}\text { Linguistic } \\
\text { Values }\end{array}$ & MF Type & $\begin{array}{l}\text { Universe of } \\
\text { Discourse }\end{array}$ \\
\hline Water Quality & $\begin{array}{l}\text { Poor } \\
\text { Average } \\
\text { Normal }\end{array}$ & $\begin{array}{l}\text { trimf } \\
\text { trimf } \\
\text { trimf }\end{array}$ & $\begin{array}{l}{\left[\begin{array}{lll}0 & 0 & 0.5\end{array}\right]} \\
{\left[\begin{array}{lll}0.3 & 0.5 & 0.7\end{array}\right]} \\
{\left[\begin{array}{llll}0.5 & 1 & 1\end{array}\right]}\end{array}$ \\
\hline
\end{tabular}

Fig. 1 shows the concept of the fuzzy inference model of this study.

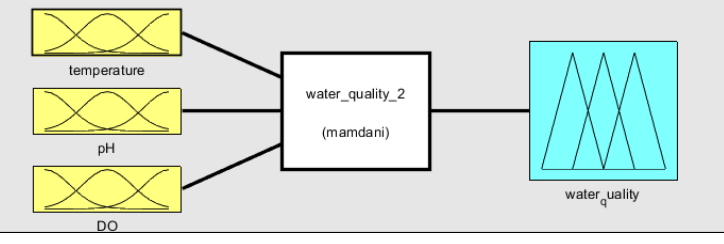

Fig. 1. Water Quality Fuzzy Inference System Model

Fig. 2 to 4 shows the design for each water parameter as shown in their captions.

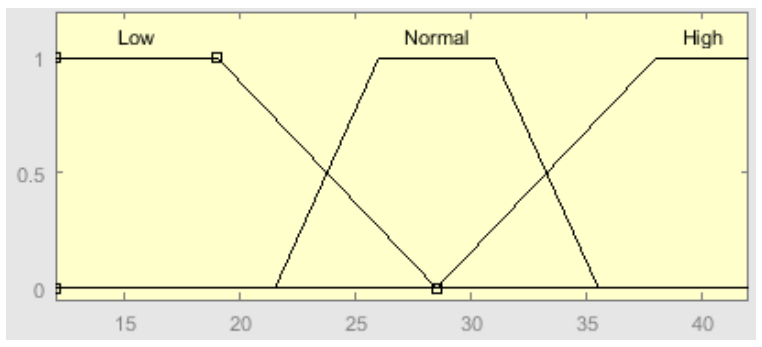

Fig. 2. Temperature Membership Function.

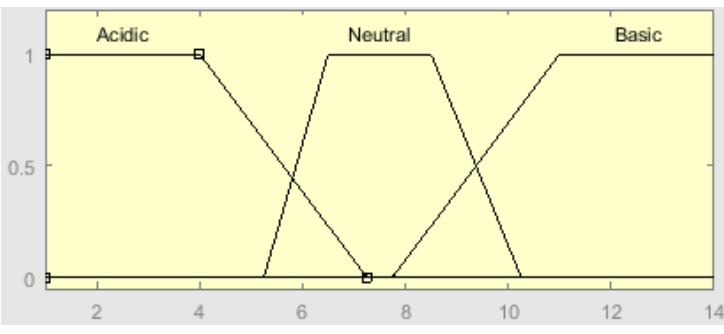

Fig. 3. pH Level Membership Function.

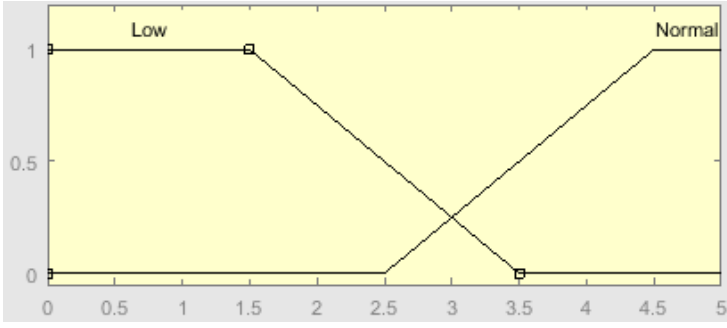

Fig. 4. Dissolved Oxygen (DO) Membership Function.

Fig. 5 illustrates the model for the overall water quality.

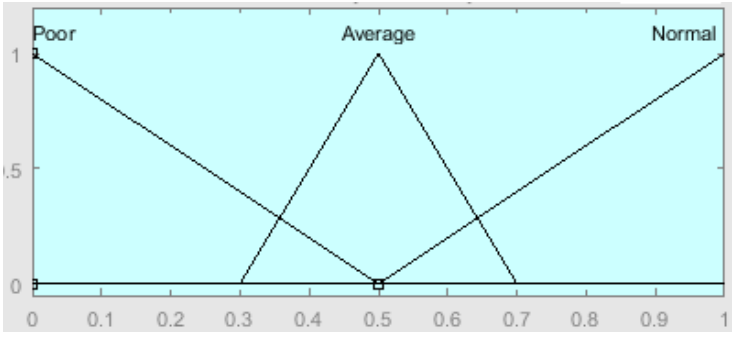

Fig. 5. Water Quality Membership Function.

With the assistance and guidance of the expert in Tilapia aquaculture, eighteen rules were generated for the model.

\section{Development of the AquaStat Device}

Arduino Uno was mainly used as the microcontroller of the device. The device is equipped with three (3) ATLAS sensors, namely: $\mathrm{pH}$ Sensor, dissolved oxygen (DO) sensor, and temperature sensor. Also, this device has a data logger and LCD to display the sensor readings and the overall water quality.

Arduino IDE was used to write the code and the fuzzy logic implementation of this paper.

Fig. 6 shows the actual AquaStat device.

Fig. 7 shows the conceptual model of AquaStat with fuzzy inference system.

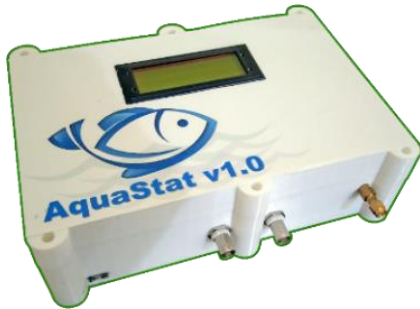

Fig. 6. AquaStat Device. 

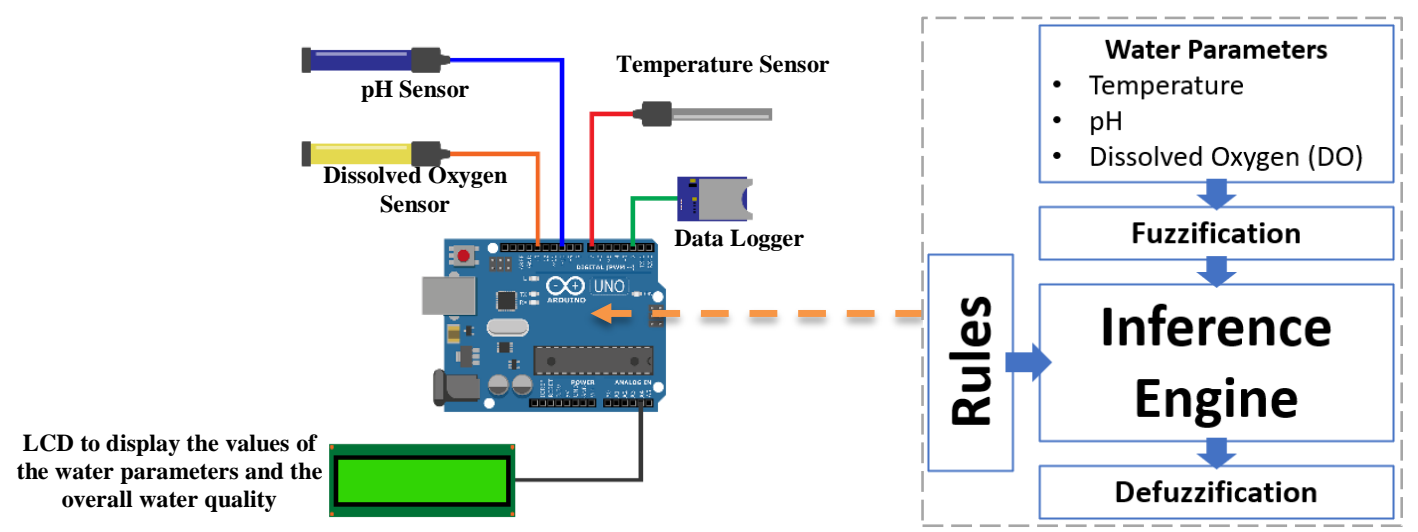

Fig. 7. Conceptual Model of AquaStat.

\section{RESULTS AND DISCUSSION}

\section{A. Accuracy in Gathering Water Parameter Values}

The testing of AquaStat was done in five (5) fish cages at the Fish Health Laboratory, Bureau of Fisheries and Aquatic Resources, San Mateo, Isabela, Philippines with the assistance of Dr. Henry Centeno, Fish Health Specialist.

To determine the extent of the accuracy of AquaStat in terms of reading the water parameters, comparison was made against the obtained readings of LaMotte Fresh Water Aquaculture Test Kit which is currently being used in the said laboratory.

Table III shows the obtained $\mathrm{pH}$ level of the water in five (5) fish cages.

The obtained $\mathrm{pH}$ values from the sample fish cages showed differences having a mean of 0.14. However, since the LaMotte Fresh Water Aquaculture Test Kit is a manual device and only capable of reading $\mathrm{pH}$ values with limited and exact decimal values, such differences in decimal values are considered insignificant.

Table IV shows the obtained dissolved oxygen level of the water in the five (5) fish cages.

The obtained DO values from the sample fish cages showed differences having a mean of 0.13 . However, since the LaMotte Fresh Water Aquaculture Test Kit is a manual device and only capable of reading DO values with limited and exact decimal values, such differences in decimal values are considered insignificant.

TABLE III. PH READINGS USING AQUASTAT AND LAMOTTE FRESH WATER AquACUlture TEST KiT

\begin{tabular}{|l|l|l|l|}
\hline Cages & AquaStat & $\begin{array}{l}\text { LaMotte Fresh Water } \\
\text { Aquaculture Test Kit }\end{array}$ & Difference \\
\hline Fish Cage 1 & 9.14 & 9 & .14 \\
\hline Fish Cage 2 & 8.21 & 8 & .21 \\
\hline Fish Cage 3 & 8.17 & 8 & .17 \\
\hline Fish Cage 4 & 7.67 & 7.5 & .17 \\
\hline Fish Cage 5 & 7.53 & 7.5 & .03 \\
\hline Mean Difference & & $\mathbf{0 . 1 4}$ \\
\hline
\end{tabular}

TABLE IV. DISSOLVED OXYGEN (DO) READINGS USING AQUASTAT AND LAMOTTE FRESH WATER AQUACULTURE TEST KIT

\begin{tabular}{|l|l|l|l|}
\hline Cages & AquaStat & $\begin{array}{l}\text { LaMotte Fresh Water } \\
\text { Aquaculture Test Kit }\end{array}$ & Difference \\
\hline Fish Cage 1 & 3.43 & 3.3 & .10 \\
\hline Fish Cage 2 & 2.72 & 2.6 & .12 \\
\hline Fish Cage 3 & 3.83 & 3.7 & .13 \\
\hline Fish Cage 4 & 2.61 & 2.5 & .11 \\
\hline Fish Cage 5 & 2.87 & 2.7 & .17 \\
\hline \multicolumn{2}{|l|}{ Mean Difference } & $\mathbf{0 . 1 3}$ \\
\hline
\end{tabular}

Table $\mathrm{V}$ shows the obtained water temperature in the five (5) fish cages.

TABLE V. WATER TEMPERATURE READINGS USING AQUASTAT AND LAMOTTE FRESH WATER AQUACULTURE TEST KIT

\begin{tabular}{|l|l|l|l|}
\hline Cages & AquaStat & $\begin{array}{l}\text { LaMotte Fresh Water } \\
\text { Aquaculture Test Kit }\end{array}$ & Difference \\
\hline Fish Cage 1 & 29.33 & 29.30 & .03 \\
\hline Fish Cage 2 & 29.27 & 29.20 & .07 \\
\hline Fish Cage 3 & 28.87 & 28.80 & .07 \\
\hline Fish Cage 4 & 29.35 & 29.30 & .05 \\
\hline Fish Cage 5 & 28.91 & 29.80 & .11 \\
\hline \multicolumn{2}{|l|}{ Mean Difference } & $\mathbf{0 . 0 7}$ \\
\hline
\end{tabular}

The obtained water temperature values from the sample fish cages showed differences having a mean of 0.07 . However, since the LaMotte Fresh Water Aquaculture Test Kit is a manual device and only capable of reading water temperature values with limited and exact decimal values, such differences are considered insignificant.

\section{B. Accuracy in Assessing the Overall Quality of the Water}

To further evaluate the accuracy of AquaStat in identifying the overall quality of the water, actual historical data of the water parameters during the regular monitoring activities of the concerned agency were used as inputs for each respective water parameter in the simulation process, Fig. 8. 


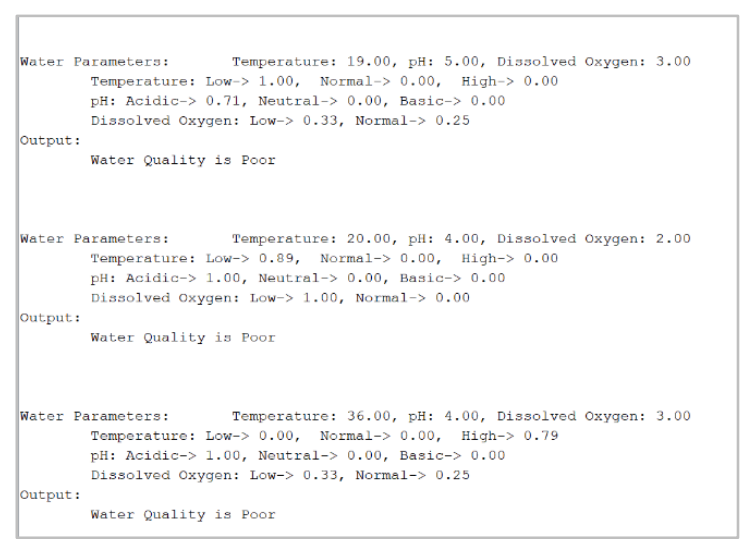

Fig. 8. Simulation of the Program using Arduino IDE
Table VI shows the results of identifying the overall water quality of the water using the historical data by the Fish Health Specialist and AquaStat. Using the given historical data, the researcher asked Dr. Centeno to evaluate and identify the overall water quality based on his own assessment. The researcher then used the given historical data and inputted them to AquaStat, and the following results were drawn.

Table VI presents the overall analysis of the water quality by the Fish Health Specialist and AquaStat using the actual historical data. The historical data are consisted of values per water parameter. The results of the overall water quality evaluation generated by AquaStat using the collected actual historical data were found to be in consonance with the overall water quality given by the Fish Health Specialist.

TABLE VI. Overall Analysis of the Water Quality by the Fish Health Specialist and AQuaStat using the Actual Historical Data

\begin{tabular}{|c|c|c|c|c|}
\hline \multicolumn{3}{|l|}{ Water Parameters } & \multirow{2}{*}{$\begin{array}{l}\text { Result of the Assessment by } \\
\text { Fish Health Specialist }\end{array}$} & \multirow{2}{*}{$\begin{array}{l}\text { Result of the Assessment using } \\
\text { AquaStat }\end{array}$} \\
\hline Water Temperature $\left(\left(\right.\right.$ in $\left.^{\circ} \mathrm{C}\right)$ & Dissolved Oxygen (in $m g / L$ ) & $p H$ & & \\
\hline 33.57 & 2.57 & 7.7 & Poor & Poor \\
\hline 31.43 & 4.49 & 9.4 & Average & Average \\
\hline 33.20 & 4.15 & 7.5 & Normal & Normal \\
\hline 33.67 & 2.78 & 7.3 & Poor & Poor \\
\hline 33.13 & 2.63 & 7.4 & Poor & Poor \\
\hline 33.21 & 4.59 & 7.4 & Normal & Normal \\
\hline 32.08 & 1.12 & 7.2 & Poor & Poor \\
\hline 33.25 & 1.49 & 7.5 & Poor & Poor \\
\hline 28.45 & 1.21 & 7.1 & Poor & Poor \\
\hline 30.40 & 1.53 & 6.6 & Poor & Poor \\
\hline 26.83 & 4.56 & 7.8 & Normal & Normal \\
\hline 28.19 & 4.37 & 8.2 & Normal & Normal \\
\hline 25.14 & 4.45 & 8.5 & Normal & Normal \\
\hline 29.20 & 3.67 & 8.0 & Normal & Normal \\
\hline 28.77 & 3.09 & 7.5 & Normal & Normal \\
\hline 28.69 & 4.97 & 6.2 & Normal & Normal \\
\hline 29.51 & 4.14 & 8.0 & Normal & Normal \\
\hline 31.30 & 5.11 & 8.3 & Normal & Normal \\
\hline 32.13 & 3.66 & 8.1 & Normal & Normal \\
\hline 31.03 & 4.07 & 8.9 & Normal & Normal \\
\hline
\end{tabular}

\section{CONCLUSION}

Fish kill events in Tilapia aquaculture in the Philippines are undeniably bringing negative impacts in the lives of the Filipino Tilapia fish farmers and the consumers. Undeniably, it is difficult to accurately predict as to when fish kill events will occur, however, having preemptive measures can lessen its devastating effect.

Based on the results, readings of the important water parameters such as $\mathrm{pH}$, dissolved oxygen and temperature using AquaStat showed promising accuracy compared to the device that is currently being used by the subject agency having mean difference of $0.14,0.13$ and 0.07 , respectively.
Also, AquaStat can accurately determine the overall quality of the water by using the human reasoning applied to it using Fuzzy Logic obtaining a 100\% accuracy.

Hence, the results and the concept of this study can be used in another study on specific freshwater specie.

\section{ACKNOWLEDGMENT}

The researcher would like to acknowledge the assistance and help extended by Dr. John Henry R. Centeno III, Fish Health Specialist at the Fish Health Laboratory, Bureau of Fisheries and Aquatic Resources, San Mateo, Isabela, Philippines, johnhenrycenteno@gmail.com. 


\section{REFERENCES}

[1] Philippine Statistics Authority, "Fisheries Situation Report January to December 2020," 2021

[2] Bureau of Fisheries and Aquatic Resources, "Philippine Fisheries Profile 2017," 2017.

[3] Philippine Statistics Authority, "Fisheries Statistics of the Philippines," 2017.

[4] Philippine Statistics Authority, "2017 Commodity Fact Sheets," 2018.

[5] Philippine Statistics Authority, "Selected Statistics Agriculture on 2018," 2018.

[6] B. C. Hohls and A. L. Kühn, "Field Guide to Fish Kill Assessments," 2001.

[7] Bureau of Fisheries and Aquatic Resources BFAR-PHILMINAQ, "Managing Aquaculture and Its Impacts: A Guidebook for Local Governments," 2007.

[8] G. S. Jacinto, "Fish Kill in the Philippines — Déjà Vu," Sci. Diliman, vol. 23, no. December, pp. 1-3, 2011.

[9] L. A. Helfrich, E. Specialist, W. Sciences, V. Tech, S. A. Smith, and V. Tech, "Fish Kills: Their Causes and Prevention Fish Diseases and Parasites Collecting and," 2009.

[10] B. Sarmiento, "Lake Sebu fish kill destroys P20M worth of tilapia | MindaNews," MindaNews, Jan. 12, 2021.

[11] M. S. Chavan, V. P. Patil, S. Chavan, S. Sana, and C. Shinde, "Design and Implementation of IOT Based Real Time Monitoring System for Aquaculture using Raspberry Pi," Int. J. Recent Innov. Trends Comput. Commun., vol. 6, no. 3, pp. 159-161, 2018.

[12] B. Shi, V. Sreeram, D. Zhao, S. Duan, and J. Jiang, "A wireless sensor network-based monitoring system for freshwater fishpond aquaculture," Biosyst. Eng., vol. 172, pp. 57-66, 2018.

[13] C. Dupont, P. Cousin, and S. Dupont, "IoT for aquaculture 4.0 smart and easy-to-deploy real-time water monitoring with IoT," 2018 Glob. Internet Things Summit, GIoTS 2018, 2018.

[14] Y. T. Liu et al., "A solar powered long range real-time water quality monitoring system by LoRaWAN," 2018 27th Wirel. Opt. Commun. Conf. WOCC 2018, pp. 1-2, 2018.
[15] B. M. Mathisen, P. Haro, B. Hanssen, S. Björk, and S. Walderhaug, "Decision Support Systems in Fisheries and Aquaculture: A systematic review," no. November, 2016.

[16] R. B. Caldo and E. P. Dadios, "Fuzzy logic control of water quality monitoring and surveillance for aquatic life preservation in Taal Lake,' IEEE Reg. 10 Annu. Int. Conf. Proceedings/TENCON, 2012.

[17] D. Rana and S. Rani, "Fuzzy logic based control system for fresh water aquaculture: A MATLAB based simulation approach," Serbian J. Electr. Eng., vol. 12, no. 2, pp. 171-182, 2015.

[18] M. H. H. Ichsan, W. Kurniawan, and M. Huda, "Water Quality Monitoring with Fuzzy Logic Control based on Graphical Programming," TELKOMNIKA (Telecommunication Comput. Electron. Control., vol. 14, no. 4, p. 1446, 2016.

[19] T. Haiyunnisa, H. S. Alam, and T. I. Salim, "Design and implementation of fuzzy logic control system for water quality control," Proc. 2nd Int. Conf. Autom. Cogn. Sci. Opt. Micro Electro-Mechanical Syst. Inf Technol. ICACOMIT 2017, vol. 2018-Janua, pp. 98-102, 2017.

[20] P. B. Bokingkito and L. T. Caparida, "Using fuzzy logic for real - Time water quality assessment monitoring system," ACM Int. Conf. Proceeding Ser., pp. 21-25, 2018.

[21] BFAR-NFFTC, "Basic Biology of Tilapia," NFFTC Aqua-Leaflet No. 2000-06. 2000.

[22] Philminaq, "Water Quality Criteria and Standards for Freshwater and Marine Aquaculture," Mitigating impact from Aquac. Phillippines, pp. 1-34, 2007.

[23] Aquatic Systems: Lake and Wetland Services, "Florida Fish Kills." 2100 NW 33rd St., Pompano Beach, Florida.

[24] J. K. Buttner, R. W. Soderberg, and D. E. Terlezzi, "An introduction to water chemistry in freshwater aquaculture," NRAC Fact Sheet, no. 170 Northeastern Regional Aquaculture Center, University of Massachusetts, North Dartmouth, Massachusetts, 1993.

[25] E. H. Mamdani and S. Assilian, "An experiment in linguistic synthesis with a fuzzy logic controller,” Int. J. Man. Mach. Stud., vol. 7, no. 1, pp. $1-13,1975$. 